\title{
THE RELATION BETWEEN ECONOMICS AND POLITICS.
}

\begin{abstract}
[Opening Address at the Annual Meeting of the American Economic Association.]

In some respects economic science is now at the height of its prosperity. At no previous period has popular interest in the subject been so widespread. Our college classrooms are thronged with its students. Teachers in our secondary schools are striving to find a place for it in their curricula. For university extension lecturers in this domain the demand far outruns the supply. Editors of all our leading journals seek for writers educated in political economy. Large business corporations demand expert statisticians for aid in the solution of their most difficult problems. In education, in journalism, or in finance, the trained economist to-day finds a great and growing demand for his services.

But in one vital respect the conditions are far less satisfactory. The influence of our economists on government and legislation is not only less than it should be to-day, but less than it many times has been in the past. Our practical politicians-" and by practical politics we do not mean foul politics "have an ill-concealed contempt for a class of men whom they regard as theorists and visionaries. In individual cases, they sometimes ask the advice of economists, and-more rarelytake it; but they are far from having the habit of asking or taking such advice as an incident to the working of government machinery. The application of civil service examinations as a means of filling administrative offices has not merided matters in this respect. Rather has it emphasized the lack of influence of economic science on governmental practice; for it has filled our public service with men technically trained in other branches of knowledge rather than that which we represent. I am not, indeed, unmindful of the valuable work which has been dorre and is being done by members of this association, on problems of currency and taxation, on price statistics, on railroad statistics, and other matters of public moment. But the very excellence of this work only emphasizes the contrast between the subordinate position and precarious influence which is to-day accorded them, and the commanding places attained by economists of the earlier generation. Where can
\end{abstract}


we find among our younger men those who are succeeding to the inheritance of Walker and Wells, of Charles Francis Adams and Horace White? One of these economists was given scope for his powers as superintendent of the census; another, as commissioner of the revenue. The record of their work has passed into history; it is a history of scientific study and practical influence combined, which reads almost like romance when contrasted with some of the administrative methods of the present day. The third of these men, as a Massachusetts public official, created a system of railroad legislation which, whatever its deficiencies, has nevertheless left its impress on the law of two continents; the fourth has proved himself the mightiest champion of the cause of sound public finance in the country, and has made the journal which he edits second to none in the world as a power for influencing public opinion and public action. Where shall we look for their successors? We are teaching more about the theory of utility than did our fathers, but are we doing so much for the realization of that theory in the organized life of the nation?

If we fail in our influence upon public life we fail in what is the most important application of our studies, and what may almost be said to constitute their fundamental reason for existence. Even if such failure represent but a passing phase, as I believe it does, it is nevertheless a most serious matter for consideration. Let us strive to-night, if we may, to get some light on this loss of economic influence. Let us see why economics and politics have grown apart in the immediate past, and consider whether there is any hope for their reunion in the immediate future.

It is hardly necessary to say that the conception of economic theory has fluctuated widely from age to age, and that the sphere of economic study has altered correspondingly. Going back in the history of this science, as we must in so many others, to Aristotle, we find that in his mind the relations between economics and politics were simple. Economics meant to him the art of ordering the affairs of a household, politics the art of ordering the affairs of a state. Each had its own clearly defined field of enquiry. The two subjects had indeed points of similarity; a man who was familiar with - the one was better prepared thereby to deal with the other; but fundamentally their spheres were as distinct as those of geography and astronomy. As a part, and a subordinate part, of the science of economics, Aristotle was forced to notice the more unworthy science, or rather art of chrematistics, - the science or art of making 
money. It is notorious that Aristotle looked upon this part of the subject with disapproval. His idea of business was like that of Mr. Caleb Garth in Middlemarch, to whom it "never meant moncy transactions, but the skillful application of labor." But in the minds of Aristotle's successors the subject of money and money-making assumed constantly increasing importance in the study of private economy. This was in fact an almost necessary consequence of substituting the labor of freemen for the labor of slaves. If the householder was able to obtain labor by physical compulsion he could despise money and all things connected therewith; but if he had to buy his labor he was forced to pay attention to the means of buying it. Thomas Aquinas had no more love for money-getting than did Aristotle, but the social conditions of the time of Thomas Aquinas rendered it necessary to take more account of money-getting than did the social conditions of the time of Aristotle. It was also gradually seen that money economy formed a better means of public service than the older system of slave labor. Not only did a wage system substitute itself for a system of compulsory or customary services, but even the taking of interest, at first unreasonably condemned, was afterward tolerated and ultimately defended by publicists. In the middle of the seventeenth century the term economy had come to be associated almost exclusively with the work of money-getting. More than this, the principles of chrematistics, or of economy in its modern sense, were applied to the conduct of public affairs, and gave rise to the study of political economy, in which ideas derived from the study of private business were applied to the work of the statesman. The cameralists applied the methods of domestic economy to matters of public finance-the conduct of the business affairs of the government. The mercantilists went yet farther, and tried to apply these same methods by legislation to the affairs of the whole people as well as of the government itself. In other words, they proclaimed the duty of the statesman to assist his people as well as his government in making money. At the end of the seventeenth century political economy was universally understood as an attempt to apply the principles of money-getting to the conduct of national affairs; and with this practice in view it was assiduously studied by financiers and by statesmen.

The eighteenth and nineteenth centuries have witnessed a reaction. It began with the French school of physiocrats, who protested against the aims of the mercantilists and combatted the idea that national wealth could best be subserved by 
national money making; contending that the food of the people rather than the gold or silver in circulation measured the national prosperity. It was carried still further by the English economists of the school of Adam Smith, who criticised the means adopted by the mercantilists no less than their aims, and showed how individual freedom conduced to the development of public wealth, in many cases at any rate, far more surely than legislative activity. A new conception of political economy thus arose, with broader aims and broader foundations than the old. It is not necessary to say to an audience like this how great was the gain both in scientific truth and in practical utility. It is perhaps more necessary to point out some of the dangers which attended the change.

In the first place, there was often a loss of concreteness. The older political economy expressed its results in pounds, shillings and pence. They might be true or they might be false, but they were at any rate in a form where they were capable of measurement and verification. Not without good cause did the mercantilists claim for their reasonings the title of political arithmetic. We may apply to them the words, at once appreciative and critical, which Bagehot applied to George Cornewall Lewis: "Of course he was not uniformly right-there were some kinds of facts which he was by mental constitution not able wholly to appreciate; and his view of every subject, though it might not be adequate, was always lucid. His mind was like a registering machine with a patent index: it took in all the data, specified, enumerated them, and then indicated with unmistakable precision what their sum total of effect precisely was. The index might be wrong; but nobody could ever mistake for a moment what it meant and where it was." In this respect later political economists are at a disadvantage. The new political economy substituted a vaguer conception of wealth for the more concrete one, and many of its propositions suffered a corresponding loss of clearness and precision. The mercantile school of economists had measured wealth in terms of money. The first generation of their critics measured it in terms of food; the second and third generation measured it as "commodities;" our own generation measures it in terms of utility. But food is a less definite and tangible measure than money; commodities are a less definite and tangible measure than food; and utility is perhaps the least definite and tangible measure of all. People know exactly how the propositions of Sir Thomas Mun applied to any concrete case; they knew approximately how those of Turgot applied; they can make a 
fair guess how those of Ricardo or Mill apply; but of the application of those of Sax or Menger they can hardly hazard a conjecture.

And in the second place, with this loss of concreteness of conception came a loss of definiteness of aim; the almost inevitable result of substituting the principles of a science for the practice of an art. This change was hardly noticed in the first generation, when Turgot and Smith and their followers were chiefly occupied sweeping away old restrictions; but when it became a question of building up rather than of pulling down the loss was felt very strongly. The old political economy very often gave wrong advice, but at the very worst it it was explicit and consistent advice. The new political economy in its anxiety to avoid error falls into vagueness of advice, and into apparent if not real inconsistency. For a presumptuous claim of knowledge it substitutes either controversies or confession of ignorance.' "Fools rush in where angels fear to tread;" but this difference of political method has at times the disadvantage of lessening the practical influence of angels upou the affairs of this world. As the art of political economy gave place to the science of economics it was placed at an inevitable disadvantage with those who sought for the easily mastered rules of an art which professed to teach them what they could do rather than the general principles of a science which too often indicated only what they could not do.

This was not the fault of the political economists. It was their fault, however, that when the problem of securing practical influence became harder, they did not make more vigorous efforts to render their points clear to the statesman, but oftentimes took refuge in the seclusion of the schools, and there built up theories of society more interesting and profitable to the scientist than to the politician. The number of students who sought their lectures increased this temptation. Instead of making it a science for statesmen they were led to make it a science for schoolmen, with all that complex termonology which Giddings so aptly calls its jargon. In many cases this process has gone so far as to make economics a subordinate department of psychology rather than politics; a theory of motives starting from assumptions that are never realized completely and ending in propositions that can never be verified at all. I am far from wishing to cast ridicule on metaphysical methods of political economy. Cournot and Jevons and the Austrian school have taught us a great many things that we did not know before. They have substituted good underlying meta- 
physics for bad underlying metaphysics. But the very excellence of this foundation has tended to divert attention from the details of the superstructure, which after all are the ones with which we have to deal in practical life. And I am disposed to think seriously that the excessive use of psychological terms and conceptions, to the neglect of purely commercial ones, has been the most potent cause to weaken the influence of economists among statesmen and men of the world.

Meantime theories of government and governments themselves were in the midst of a process of evolution which tended to carry them somewhat away from the influence of economic theory, even if that theory had remained the same. The judiciary, the legislature and the administration were subject each of them to separate influences which made them less ready to rely on the political economist for advice and guidance.

It might be thought that the judiciary, at any rate, would never have become independent of economic considerations; for the scientific study of the law has had and still has a close affiliation with the scientific study of political economy. This affiliation between economics and jurisprudence is manifest alike in their data, their methods, and their conclusions. The fundamental datum of modern economics is property right. This is also the datum and starting point of a large part of our legal reasoning. The method of the economist is a combination of the historical and the deductive. He studies the precedent by which property right has been established on the one hand, and deduces the consequences arising from such property rights on the other hand. This combination is also characteristic of the methods of the judiciary; the chief difference between economists and court being that the economist considers how the individual judgment will act under the given conditions, while the court considers how the public judgment will act. But this difference of standpoint ought not to lead to conflicting or even inharmonious conclusions, for the economist shows over and over again how freedom of individual judgment results in collective good, and the judiciary shows with equal force how the free activity of public judgment in the pursuit of its own ends leads to the highest measure of individual good. Finally, the characteristic conclusions and precepts of the modern political economists are summed up in the two words "free competition;" and this is no less characteristically the conclusion and precept of our law courts. In relying on competition to liberalize commercial practice, econ- 
omists and lawyers have gone hand and hand; sharing in tolerably equal measure the glory of habitual success in its application, and the odium of occasional error by its misapplication.

But economics and law have to some degree parted company; not so much in hostility as in indifference, not so much in denying one another's conclusions as in ignoring them. In the earlier times economists and jurists were both concerned to connect their principles with those of political ethics, and each science was thus brought into vital connection with the other. But just as economics gradually assumed the character of a science or discipline by itself, based upon the action of each individual in deciding what was for his own utility and making this exercise of individual jndgment an absolute fact if not an absolute right; so jurisprudence at almost the same time became an equally absolute science based upon the actions of a public will, the judgments of a sovereign who allowed no control except that which his own pleasure deigned to impose. This doctrine of sovereignty as a basis of jurisprudence has a history closely parallel to that of the doctrine of utility as a basis of economics. Until the end of the eighteenth century the authority of the law was based upon the supposition of a social compact. People obeyed the government because the government rendered certain services to the people. That such a compact or contract ever existed historically the leading exponents of the theory did not believe or even pretend to believe. Rousseau himself explicitly says that it makes no difference with his social contract theory whether it had any historical basis or not. It was an assumption used to give vitality and concreteness to the conceptions of that natural justice to which eighteenth century writers held that law must conform. Hobbes and Locke and Blackstone and Roussear, with all their wide divergences of opinion on individual points, were united in holding to this theory of a compact. Hobbes might use it to deny the right of revolution, Locke to prove that same right; Blackstone might use it as a conservative force, Rousseau as a destructive one. But absolutists and revolutionists, conservative and radical, all had before them the conception of a higher law of political necessity limiting the actions of the courts, just as the economists of the same period held to the conception of public needs and claims as limiting the economic action of the individual. It was reserved for Bentham to deal the death blow to this theory; to show not only that the social compact had no foundation in history - which was an easy enough task, because nobody really thought it had-but also no foun. 
dation in logic; to insist that so-called natural law was no law at all; that law was what the courts said, just because the courts chose to say it and for no other reason whatever. When a certain court objected to Daniel Webster's logic, "this is not law," "It was law until your honor spoke," was the historic reply.

Of the practical gain in clearness of legal decisions resulting from the acceptance of the theories of Bentham there can be no dispute; but it was a gain which has been purchased at a very serious cost. The courts have been estopped from talking no small amount of nonsense, but they have also lost no small part of their educational influence which they had under the old system. For Bentham may be said to have overthrown a theory which was historically false and prophetically true, and substituted one which was historically true and prophetically false. As a matter of history things have been law, not because they were just or even logical, but because the courts enunciated them. But it is safe to prophecy that this state of things will continue so long as the courts are respected by the public as being at once just and logical. It is right as well as convenient for the lawyer to assume that whatever the courts command will be law; but only because the courts show themselves clearer sighted than the body of the nation. The authority of the English judges, while nominally derived from the crown, has been practically derived from their own good sense and progressiveness. A theory which leads them to rely more on precedent and less on good sense and progressiveness, while it may prevent the more commonplace judges from making an exhibition of themselves, nevertheless offered a serious bar to the development of legal authority to meet new circumstances and new emergencies, not to speak of the possibility that it may at times menace the general respect for the judiciary and general authority of the law as a whole. As a matter of fact, the courts have made themselves independent of the help of the economists by withdrawing from the consideration of those distinctively modern problems where precedent furnishes no clear guide for action. In making the corpus juris clearer and more consistent with itself, it would seem to a layman as if the courts have sometimes fallen short of meeting the needs of growing industrial communities. Contrast the rapid progress of English law down to the middle of the last century in all economic matters, where judges were among the most enlightened of reformers, with its extremely slow development in the face of modern conditions. Take the matter of taxation. Have judicial decisions adapted 
themselves to facts? No. They are based on assumptions as to the possibility of assessment of personal property which may have been approximately true in the eighteenth century, but are totally false in the nineteenth: The courts, while protesting against unequal taxation, nevertheless refuse to look at the chief practical source of inequality, that source not having been a thing of great importance a hundred years ago. Or take the matter of transportation. For a generation and more our courts insisted on applying to the railroad the precedents derived from the highway. It is not so very many years since they refused to enter.upon that most important of all railroad rate evils, the evil of discrimination; in some instances saying explicitly that if one man's rate was reasonable in itself it was irrevelant to inquire whether another man was charged a lower rate. Such instances of lack of attention to modern facts might be multiplied indefinitely, but these are enough to show how the legal theory of sovereignty of the court has had the same effect as the economic theory of sovereignty of the individual in separating trom one another, and from the needs of practical politics, two sciences whose best work has been done hand in hand with each other, and in the most sedulous application to those needs.

The results of this separation have been so serious that efforts have been made to reintroduce a connection by means of "commissions" of various forms-railroad commissions, tax commissions, labor commissions, and an indefinite number of others. Such bodies, it is thought, will, like the courts, represent public opinion; but unlike the courts they will be possessed of technical knowledge which will enable them to look forward to the future and not merely backward at the past. On the work of these commissions, as a whole, there is no need of passing judgment or balancing their good and their evil. Suffice it to say that they have too often proved a wholly extra. neous element in the development of the law; and that in assuming quasi-judicial functions they have antagonized the courts instead of helping them. As a matter of principle, the attempt to supplement courts by commissions, involving as it does a separation of the progressive from the conservative, of the technically instructed from the legally instructed, is questionable in theory and likely to produce conflicts in practice. As a matter of political experience $I$ think it is safe to say that technically trained commissions have proved themselves more valuable as assistants to the legislature or the administration than as supplements to the activity of the courts. 
But why did not this conservatism of the courts give the economists all the greater opportunity to influence the legislature, either directly or through legislative commissions? If the courts became the exponents of precedent, why could not Parliaments, with the assistance of just such commissions as have been described, be the champions of progress? Was there - not here a field for the activity of economic experts, who, seeing farther than their fellows, could give advice which should be followed and should stand? As economists lost the chance to infuence judicial decisions, were they not face to face with a wider field for influencing legislative debates?

For the better part of a century this possibility existed. In fact, it may have been said to have lasted nearly as long: as legislative debate itself lasted. But the days of legislative debate are numbered, if, indeed, they are not already ended. Congresses and Parliaments have been compelled to abandon their watchword of free speech and to adopt in one form or another the principle of closure. The system of representative government devised originally as a check upon the administration, and admirable as a means of giving free discussion to measures of a more or less independent administration, has not proved equally successful as a means of discussing actual business in its initiative stages. "Armies," says Macaulay, "have won victories under bad generals, but no army ever won a victory under a debating society." For the actual conduct of public business the legislature is at once an unwieldy and irresponsible body. It is so, in the first place, on account of its numbers. When the object of a Parliament was to form and impress public opinion, a large body of members was indispensable. When the object is to manage the actual business of government intelligently, numbers are a hindrance rather than a help. The difficulty is heightened by the prevalence of the bicameral system. When the object was the creation of public sentiment, two houses secured twice as much publicity. When the object is dispatch of public business, two houses result in divided responsibility, with all the consequent delay and chicane. And finally, the system of district representation, at first admirable as a means of representing all the different sections of the community, becomes under the new conditions a positive disadvantage. In the creation of public sentiment, it gave us an exchange of opinions; in the dispatch of public business it means exchange of favors. Instead of co-operation in the general interests we have log-rolling for particular interests. Under the current system of political ethics there is in fact a 
direct antagonism between the theory of economics and the practical working of representative government. The economist shows how largely the independent action of the parts may be made to conduce to the collective good of the whole. The practical working of representative government, making each member primarily responsible to his district-or one might better say to the members of his own party in his district-means that the collective action of the whole is made a means to fulfil the separate wants of the parts, even though the satisfaction of those wants may antagonize the general interest of the nation. The history of every tariff bill and of every river and harbor bill affords illustrations of this tendency of our representative system. The economist is at a disadvantage in influencing members of the legislature, because his ends are different from theirs. $\mathrm{He}$ is trying to pursue collective interests; they are trying-and under the existing condition of things, necessarily trying-to balance, to compromise, or in some fashion to reconcile divergent ones.

This difference of aims, which puts the economist at a disadvantage in dealing with the legislature, ought apparently to put him at a corresponding advantage in advising the executive. For the head of the executive department, be he wise or unwise, disinterested or self-seeking, nevertheless regards himself as a representative of the whole people rather than of small sections of the people. It would seem that such an executive, on whom the nation relies for progress in the face of judicial conservatism, and for wise collective action in the face of legislative particularism, would feel more than ever the need of advice from trained economists to guide him in the work of administration. That such need exists and is felt is unquestionably true; and where the administration has power to carry out a policy of its own the advice of economic experts is habitually sought and frequently followed. But it is not always the case that the administration has this power to carry out a policy of its own. For centuries we have been busy devising constitutional checks of the royal prerogative. We have had so much reason to fear usurpations of power on the part of the executive that we have not left him that modicum of power which is needed for good government. If he has to face an adverse majority in the legislature he is tied hand and foot. If his own party controls the legislature he must consult the representatives of the various districts and pay the price which they exact for supporting his measures; and he is too often reduced to the yet more questionable expedient of seeking support for his re- 
nomination and re-election in order to have time to give his policy a fair trial. Under such circumstances he is often compelled to be a politician first and a statesman afterward. However much he may desire the advice of economists and even avail himself of their services, he is frequently bereft of the power to utilize them; and it too often happens that the economists, in their encouragement of independent voting on each national issue as it arises, deprive themselves of that influence within the party councils which is necessary for carrying any issue whatsoever to its logical test and conclusion.

But things are by no means at their worst. On the contrary, if we compare the conditions of to-day with those of thirty years ago, we see an increase of economic methods and economic influence in some parts of the work of government. Particularly true is this in municipal affairs. It was there that the need for a good business administration came most directly home to the citizens. It is there that councilmen and aldermen have suffered restrictions of their power and that real authority has been given to the executive. It is there that the credit for good business management and the discredit for bad business management can be more clearly brought home to the official with whom it belongs. And it is there, also, that the advice of economic experts counts for most. It is not an accident that so much of the careful study of problems of finance and administration is to-day dealing. with matters of municipal government; it is a consequence of that increased centralization of administrative power which gives the expert a fair chance. But the reform is not likely to stop at that point. Whatever we may think of imperialism as a sentiment or of national expansion as a policy-and I was one of those who looked upon them with regret-these are things to which we are already committed. This policy brings new problems of administration upon us as a nation, and renders it more necessary than before to study the art of national government. When we were only governing ourselves we could leave Congress to make what laws it pleased, and trust to the good sense and political education of the American people to prevent irreparable damage. But we now have to deal with peoples who have not this good sense and this political education. More than that, we have to deal with them in the sight of all the world, and in the face of hostile powers who will be only too ready to make our misgovernment a pretext for interference. We can no longer content ourselves with the laxness of method which has characterized our dealings with the inhabitants of our western territories. 
The need of an efficient army will of itself compel our people to give more independence to the administration and more opportunity to its expert advisers. The need for a government of our new colonies which shall recognize the principle of trusteeship rather than of spoliation must conduce yet more strongly toward the same result. The need of increased public revenue to meet our larger administrative expenditures will render it necessary to subordinate the demands of the several districts to the general necessities of the country. With no colonies and a small army we could do what we pleased with our revenue bills. With larger possessions and larger necessities for defense, they must be framed by a responsible administration on a sound economic basis.

Just how this change of governmental methods will come about no one can venture to predict. That we shall adopt the English system of cabinet responsibility seems unlikely; but that we shall adopt some system which will cause the different branches of our government to operate harmoniously is a foregone conclusion. The alternative is national disgrace, if not national ruin. Here is the opportunity for the younger economists of the country. If their study is worth anything it will give them a broader range of data on which to work and a clearer perception of consequences for the future. It will put them in a position of advantage in giving advice. The more responsible the government the more certain is it to take such advice. I do not say that the opportunity to become advisers and leaders of a tiational policy should be sought by econo-. mists, as their sole duty, or to the neglect of their other public responsibilities. I do not undervalue for a moment the importance of economic theory. I have the highest conception of the work of our economists as teachers of science. But I believe that their largest opportunity in the immediate future lies not in theories but in practice, not with students but with statesmen; not in the education of individual citizens, however widespread and salutary, but in the leadership of an organized body politic.

Arthur T. Hadley. 